\title{
LEVIATHANS, FEDERAL TRANSFERS, AND THE CARTELIZATION HYPOTHESIS
}

\author{
MARKO KOETHENBUERGER
}

CESIFO WORKING PAPER NO. 1180

CATEgORY 2: PUBlic CHOICE

APRIL 2004

\footnotetext{
An electronic version of the paper may be downloaded

- from the SSRN website:

www.SSRN.com

- from the CESifo website:

www.CESifo.de
} 


\title{
LEVIATHANS, FEDERAL TRANSFERS, AND THE CARTELIZATION HYPOTHESIS
}

\begin{abstract}
Federal fiscal arrangements are argued to give rise to tacit collusion among competing Leviathans (Brennan and Buchanan, The Power to Tax, CUP, 1980). Though frequently encountered in academic and policy discussions, the cartelization hypothesis has rarely been scrutinized formally. This paper explores the effect of federal equalizing transfers on Leviathans engaged in tax competition. Contrary to the hypothesis, equalization is found to potentially complement tax competition in taming the Leviathan by implicitly taxing tax revenues extracted by the Leviathan. Thus, transfers might be an appropriate constitutional provision against fiscal expropriation.
\end{abstract}

JEL classification: H7, H1, H20.

Keywords: Leviathan, fiscal transfers, fiscal competition, federalism, constitution.

\author{
Marko Koethenbuerger \\ CESifo (University of Munich \& Ifo Institute) \\ Poschingerstrasse 5 \\ 81679 Munich \\ Germany \\ mkoethen@ces.vwl.uni-muenchen.de
}

I have benefited from comments by seminar participants at the University of Munich and participants of the annual meeting of the EPCS 2003 (Aarhus). In particular, the comments by Ulrich Hange, Matthias Wrede and a referee are gratefully acknowledged. 


\section{Introduction}

Economic integration constrains governments in designing their tax systems. The enhanced option for economic resources (most notably physical capital) to locate in more tax-favorable jurisdictions inclines politicians to reduce the tax burden otherwise imposed on the resources. Though this aspect of integration appears to be robust to whether governments are benevolent or use discretionary power to pursue private agendas, the welfare implications of it critically depend on the politicians' motivation. Following the public choice view, tax competition serves as a beneficial constitutional provision to tame a Leviathan-type government. The magnified tax base elasticity is argued to effectively constrain the Leviathan in expropriating constituents (Brennan and Buchanan, 1977 and 1980).

To preserve the competitive pressure exerted by tax competition, the public choice approach recommends a "loose" federal structure in which fiscal ties between competing jurisdictions are not too dominant. Most prominently advocated by Brennan and Buchanan (1980, pp. 181-184), federal institutions designed to share tax revenues between jurisdictions are to be opposed on the grounds that they implicitly establish a cartel among competing Leviathans, undermining the boon of decentralized taxation. ${ }^{1}$ Specifically, Brennan and Buchanan conjecture that

"...the central government would act as an enforcer of the agreement between governments, doling out financial penalties to those jurisdictions which attempt to breach the agreement. ... If some state/province levied a low rate of tax in relation to some instrument over which it retained jurisdiction, other states would need to be able to penalize it by means of its grant appropriation ..." (Brennan and Buchanan, 1980, p. 182).

One mode of intergovernmental revenue-sharing, which operates in almost all federal economies, is that of fiscal equalization programs. Their potential collusive character derives from their inherent property to allocate resources to fiscally-needy

\footnotetext{
1 "Revenue sharing is undesirable, because it subverts the primary purpose of federalism which is to create competition between jurisdictions." (Brennan and Buchanan, 1980, p. 183.)
} 
regions. If the system equates tax revenues across jurisdictions - as we assume in the paper and as is the underlying principle for the equalization system among German states - lowering the tax rate in an attempt to increase tax revenues tends to be penalized by grant appropriation. Following the drop in the tax rate, the region's own mobile tax base improves, whereas tax revenues of neighboring regions deteriorate, induced by a corresponding tax base outflow. The equalization scheme responds to the fiscal imbalance by lower entitlements of the tax-lowering region and higher entitlements of the other regions. Mirroring the Brennan-Buchanan hypothesis, the revenue-sharing system appears to act as an enforcement mechanism of the tax cartel which offsets the disciplining effect of tax competition. Accordingly, Leviathans face less (or possibly even completely escape) competitive pressures at the expense of constituents' welfare.

The paper formally addresses the Brennan-Buchanan cartelization hypothesis for the class of revenue-sharing arrangements which equalize (per-capita) tax revenues across regions. We assume Leviathan governments to be subject to capital tax competition and interregional equalization at the same time. Two types of Leviathans are considered: purely and partially selfish politicians. While the former view conforms to the canonical model of a surplus-maximizing government (Brennan and Buchanan, 1980), the moderate view of politicians implicitly accounts for disciplining political institutions as well. ${ }^{2}$ The paper's contribution is as follows: In line with the fiscal cartelization hypothesis, pure Leviathans generally collude via equalizing transfers. Small regions are an exception; their taxing incentives are found to be unaffected by transfers. If Leviathans are moderate, equalization may even allow for beneficial effects judged from the constituents' perspective. Tax revenue equalization programs impose an implicit tax on resources expropriated by the Leviathan, thereby exerting further downward pressure on tax rates in addition to tax competition. Interestingly, full equalization of public funds may even perfectly tame the Leviathan's desire to divert resources. Thus, in contrast to the Brennan-

\footnotetext{
${ }^{2}$ For instance, a moderation of Leviathan behavior may be the result of democratic institutions such as voting which at least partly force politicians to take constituents' well-being into account.
} 
Buchanan conjecture, fiscal transfers cannot generally be excluded from the set of effective checks and balances devices aimed at aligning Leviathans' and constituents' interests. The diverging recommendation is rooted in the not too implausible assumption that there is a tiny amount of benevolence in the government's motivation, e.g. induced by democratic voting. The importance of explicit political constraints is well recognized in Brennan and Buchanan (1980). But the incentive effects of tax-revenue equalization programs in the presence of political constraints have not completely been accounted for when formulating the conjecture.

The existing body of literature largely concentrates on analyzing tax competition among Leviathan governments assuming away intergovernmental transfers; see e.g. Epple and Zelenitz (1981), Edwards and Keen (1996), and more recently Gordon and Wilson (2003). Epple and Zelenitz argue that tax competition cannot completely discipline the Leviathan. Additional political constraints are needed to curb the tendency to overspend. Combining the benevolent and public choice view of government, Edwards and Keen find tax competition to be welfare-enhancing, only if the selfish-part of the politicians' motivation is sufficiently pronounced. ${ }^{3}$ Gordon and Wilson show that voters can partially mitigate the political agency problem by choosing a tax mix in which property taxes play a major role. The rationale is that the property tax base is responsive to the amount of socially-productive spending. A tax mix favoring property taxes provides incentives to spend a larger fraction of total tax revenues on productive expenditures instead of on "waste".

To the best of my knowledge the notion of fiscal cartelization has so far received little rigorous formal modelling. Exceptions are Flowers (1988), Wrede (1996, 2000) and Keen (1998). They demonstrate that centralization of taxing powers and sharing of all centrally-collected tax revenues might actually benefit constituents rather than facilitate welfare-deteriorating collusion among Leviathans. Originating from a tax base overlap, joint (i.e. centralized and decentralized) taxation takes the economy onto the downward-sloping side of the Laffer-curve. The Leviathan and the

\footnotetext{
${ }^{3}$ See also Hange and Wellisch (1998). They demonstrate that some degree of decentralization is beneficial as it reduces waste in government.
} 
constituents benefit from lower tax rates implemented by exclusively assigning taxing powers to the central level. Equalizing transfers, however, make no appearance in these papers.

The role of fiscal equalization on resource allocation is well-established in the literature on fiscal federalism, but with a different focus. As pioneered in Buchanan (1952) and formalized in Boadway and Flatters (1982), tax revenue equalization tends to eliminate fiscally-induced migration incentives. While allowing one to assess how equalization shapes the decisions of private agents, neither paper disentangles the incentives imposed on government policy. Bucovetsky and Smart (2002) and Köthenbürger (2002) explicitly consider the interaction between equalization and tax policy in the presence of tax competition. Unlike the present paper, they assume benevolent governments.

The paper proceeds as follows. Section 2 introduces the model. Section 3 characterizes equilibrium Leviathan tax policy. The welfare implications are analyzed in Section 4. Section 5 discusses extensions. Concluding remarks are offered in Section 6. All proofs are relegated to the Appendix.

\section{The Model}

\subsection{Private Sector}

Consider an economy with $n>1$ identical regions each consisting of a representative household and a representative firm. ${ }^{4}$ Households derive utility from private consumption, $c^{i}, i=1, \ldots, n$. In addition to the capital endowment, $\tilde{k}$, each household inelastically supplies one unit of labor, $l^{i}=1$. Total income is, therefore, given by the sum of the wage rate, $w^{i}$, and the interest income, $r \tilde{k}$, yielding

$$
c^{i}=w^{i}+r \tilde{k} .
$$

\footnotetext{
${ }^{4}$ With symmetric regions there is clearly no demand for equalization programs. The simplification has been however adopted to focus on a rationale for fiscal equalization different from the reduction in regional fiscal inequalities traditionally focused on.
} 
Regional firms produce a numéraire consumption good according to the neoclassical production technology $f\left(k^{i}, l^{i}=1\right)$ which exhibits constant returns to scale. Firms maximize profits. Given a source-based capital tax, $t^{i}$, the profit-maximizing input choices are characterized by $w^{i}=f\left(k^{i}\right)-f^{\prime}\left(k^{i}\right) k^{i}$ and $r+t^{i}=f^{\prime}\left(k^{i}\right){ }^{5}$

Capital is perfectly mobile and is allocated across regions to equate the net return on capital, $r$. The capital market equilibrium is thus characterized by the arbitrage condition, $r=f^{\prime}\left(k^{i}\right)-t^{i}$, and the capital market clearing condition, $\sum_{j=1}^{n} k^{j}=\tilde{k}$. Differentiation of both conditions yields ${ }^{6}$

$$
\frac{\partial k^{i}}{\partial t^{i}}=\frac{n-1}{n} \frac{1}{f^{\prime \prime}(k)}<0, \quad \frac{\partial k^{-i}}{\partial t^{i}}=-\frac{1}{n} \frac{1}{f^{\prime \prime}(k)}>0, \quad \text { and } \quad \frac{\partial r}{\partial t^{i}}=-\frac{1}{n}<0,
$$

where the derivatives are evaluated at $k^{i}=k^{-i}$.

\section{$2.2 \quad$ Public Sector}

Besides having their own tax revenues from levying a source-based capital tax at a rate $t^{i} \in[0, \bar{t}]$, regions participate in a federally-mandated interregional transfer system which is conditioned on all regions' tax rates. ${ }^{7}$ The transfer component relevant for region $i$ is given by $\beta^{i}\left(t^{i}, \boldsymbol{t}^{-\boldsymbol{i}}\right)$, where $\boldsymbol{t}^{-\boldsymbol{i}}$ is a vector of regional tax rates except of region $i$ 's. Entitlement payments are determined so as to equalize tax revenues among regions of the federation. This form of equalizing transfers is for instance operative among German states; see Baretti et al. (2002). Thus,

$$
\beta^{i}\left(t^{i}, \boldsymbol{t}^{-i}\right):=\alpha\left[\frac{1}{n} \sum_{j=1}^{n} t^{j} k^{j}-t^{i} k^{i}\right], \quad \alpha \in[0,1] .
$$

Transfers are conditioned on the difference between average and regional per-capita tax revenues with parameter $\alpha$ reflecting the degree to which differences are equalized. Note, since the transfer scheme is budget-balancing, i.e. $\sum_{j=1}^{n} \beta^{j}(\cdot) \equiv 0$, a federal government financing the transfer scheme does not have to be introduced explicitly. Its role is restricted to administer the equalization system.

\footnotetext{
${ }^{5}$ Subsequently, the fixed factor is omitted from notation. $f^{\prime}\left(k^{i}\right)$ denotes the first derivative of $f\left(k^{i}\right)$ with respect to $k^{i}$. The second derivative is denoted by $f^{\prime \prime}\left(k^{i}\right)$.

${ }^{6}$ The superscript $-i$ denotes a region other than region $i$.

${ }^{7}$ The upper bound $\bar{t}$ is introduced to rule out non-interior solutions inducing an infinite tax rate.
} 


\section{Equilibrium Tax Policy}

The regional government maximizes the weighted sum of private utility, consisting of private consumption $c^{i}$, and the surplus $S^{i}$, comprising tax revenues and transfers, $S^{i}:=t^{i} k^{i}+\beta^{i}\left(t^{i}, \boldsymbol{t}^{-\boldsymbol{i}}\right) .{ }^{8}$ Therefore,

$$
t^{* i} \in \operatorname{argmax}_{t^{i} \in[0, \bar{t}]} \quad \omega c^{i}+S^{i}, \quad \omega \geq 0 .
$$

Taking the capital responses into account, differentiation of $c^{i}$ (Eq. (1)) and $S^{i}$ yields

$$
\frac{\partial c^{i}}{\partial t^{i}}=-f^{\prime \prime}\left(k^{i}\right) \frac{\partial k^{i}}{\partial t^{i}} k^{i}+\frac{\partial r}{\partial t^{i}} \tilde{k}<0,
$$

and

$$
\begin{aligned}
\frac{\partial S^{i}}{\partial t^{i}} & =\frac{\partial}{\partial t^{i}} t^{i} k^{i}+\alpha \frac{1}{n} \frac{\partial}{\partial t^{i}} \sum_{j=1}^{n} t^{j} k^{j}-\alpha \frac{\partial}{\partial t^{i}} t^{i} k^{i} \\
& =\left[1-\alpha\left(\frac{n-1}{n}\right)\right] \frac{\partial}{\partial t^{i}} t^{i} k^{i}+\frac{\alpha}{n} \frac{\partial}{\partial t^{i}} \sum_{j=1, j \neq i}^{n} t^{j} k^{j}
\end{aligned}
$$

Private consumption is unambiguously lowered by higher taxation. The impact of a marginal tax increase on $S^{i}$ can be decomposed into three effects. Firstly, a marginally higher tax rate translates into a change in a region's own tax revenues (first term in Eq. (5)). The transfer system's response is twofold. The second term in Eq. (5) describes the impact of the induced change in average tax revenues on region $i$ 's entitlement payments, while the last expression refers to the transfer response following higher tax revenues in region $i$.

Rearranging terms allows for a useful alternative interpretation of the total effect. As shown in Eq. (6) higher tax revenues are implicitly taxed by the equalization system at rate $\alpha\left(\frac{n-1}{n}\right)$. The tax rate originates from the fact that marginally higher tax revenues, $t^{i} k^{i}$, decrease transfers at a rate $\alpha$, whereas the corresponding increase in average tax revenues absorbs the drop in transfers at a rate $\frac{\alpha}{n}$. Intuitively, the implicit tax effect intensifies the competitive pressure on Leviathan tax policy beyond the level already exerted by tax competition, since not only the tax base but

\footnotetext{
${ }^{8}$ The simplified objective function allows for a thorough analysis of the incentive effects imposed by tax revenue equalization. The qualitative results carry over to more general objective functions; see Section 5.
} 
also transfers shrink in response to taxation. The implicit tax effect of transfers is counteracted by a collusion effect. Entitlement payments rise at a rate $\frac{\alpha}{n}$ as tax revenues of other regions, participating in the equalization scheme, increase; see second term in Eq. (6). Ignoring this cross-budget effect is the basis for disciplining tax competition, which is now partly overridden by fiscal equalization. Consistent with the Brennan-Buchanan cartelization hypothesis, this part of the transfer response implicitly allows for collusive tax setting among Leviathans.

The magnitude of these effects depends on the degree of equalization $\alpha$ and the size of the federation $n$. While both effects are increasing in the degree of equalization, scope for collusion is diminished whereas implicit taxation becomes more pronounced as $n$ rises. Therefore, decentralization (modelled as an increase in $n$ ) strengthens the disciplining effect of transfers. Note, the disentangled impact of a higher $n$ on $S^{i}$ is exclusively mediated by the transfer response. The simultaneous increase in the tax base elasticity, intensifying tax competition, does not explicitly enter Eq. (6). It is captured by the tax base responses in Eq. (2).

\subsection{Equilibrium Tax Policy without Transfers}

To allow for a meaningful analysis of the cartelization hypothesis, we first characterize tax policy in the absence of transfers, $\beta^{i} \equiv 0$, which subsequently serves as a reference point. Using Eqs. (4) to (6) and rearranging, the optimal tax policy follows from

$$
\epsilon^{i}=1-\omega, \quad \text { where } \quad \epsilon^{i}:=-\frac{\partial k^{i}}{\partial t^{i}} \frac{t^{i}}{k^{i}}, \quad \text { and } \quad \omega \in[0,1)
$$

The restriction $\omega<1$ guarantees an interior solution. We subsequently assume this inequality to hold, implicitly reflecting constitutional restrictions (if $\omega>0$ ) which are insufficient per-se to induce a zero tax rate. In a symmetric equilibrium, $k^{i}=\tilde{k}$. Implied by Eq. (2), the higher the value of $\epsilon^{i}$, the higher the equilibrium tax rate. Therefore, Eq. (7) establishes a negative relation between the tax rate and $\omega$. As $\omega$ lowers, the tax rate increases along the positively-sloping part of the Laffer curve. In particular, for $\omega=0$ the Leviathan reaches the maximum of the local Laffer curve. 
In what follows, let $t^{*}\left(t_{\beta}^{*}\right)$ denote the equilibrium tax rate without (with) transfers. The positive relation between the tax base elasticity and the tax rate allows us to interchangeably refer to the difference in $\epsilon^{i}$ or to the tax differential $t^{*}-t_{\beta}^{*}$ when evaluating the incentive effects of transfers in the next subsection.

\subsection{Equilibrium Tax Policy with Transfers}

In the canonical case of a pure Leviathan $(\omega=0)$ the first-order condition reads

$$
\epsilon^{i}=1+\frac{\alpha}{n(1-\alpha)}, \quad \alpha \in(0,1)
$$

for an interior solution. Proposition 1 reveals how transfers affect taxing incentives. ${ }^{9}$

Proposition 1: (Pure Leviathan) Let $\omega \equiv 0$. (i) In large open regions $(n \in(1, \infty))$ the Leviathan chooses $t^{*}<t_{\beta}^{*} \leq \bar{t}$, for $\alpha \in(0,1)$, and sets $t_{\beta}^{*}=\bar{t}$ for $\alpha=1$. (ii) Conversely, if regions are small $(n \rightarrow \infty)$, tax policy is unaffected by fiscal transfers irrespective of the degree of equalization $\alpha \in(0,1]$.

While tax competition in isolation takes the Leviathan to the peak of the regional Laffer curve, there is "overtaxation" of capital $\left(\epsilon^{i}>1\right)$ if revenue equalization is operative in a large open region (Eq.(8)). ${ }^{10}$ This is because the collusion effect dominates the implicit tax effect. Fiscal transfers partially insulate the Leviathan from capital mobility which encourages him to tax capital at a higher rate. ${ }^{11}$ In particular, with full equalization $(\alpha=1)$ the collusive effect becomes sufficiently strong

\footnotetext{
${ }^{9}$ As demonstrated in the proof (see the Appendix), Proposition 1 adopts the tie-breaking rule $t^{*}=t_{\beta}^{*}$ if $n \rightarrow \infty$ and $\alpha=1$. Otherwise, the equilibrium tax rate would not be uniquely determined.

${ }^{10}$ Paralleling findings with concurrent taxation in federal systems (e.g. Wrede (1996) and Keen (1998)), Leviathan governments find themselves on the downward-sloping side of the locallyperceived Laffer-curve.

${ }^{11}$ To see the dominance of the collusion effect indirectly, divide the first-order condition $\frac{\partial}{\partial t^{i}} S^{i}=0$ (Eq. (6)) by $0<\left[1-\alpha\left(\frac{n-1}{n}\right)\right] \leq 1$. The modified optimality condition now decomposes into the term $\frac{\partial}{\partial t^{i}} t^{i} k^{i}$, being set to zero in the absence of transfers, and a strictly positive collusion term magnified by the weight $\left[1-\alpha\left(\frac{n-1}{n}\right)\right]^{-1} \geq 1$. Equalizing-transfers unambiguously increase tax rates, revealing collusion among Leviathans. Specifically, the magnified weight attached to the collusion term, $\frac{\alpha}{n}\left[1-\alpha\left(\frac{n-1}{n}\right)\right]^{-1}$, becomes unity for $\alpha=1$. In this case, $\frac{\partial}{\partial t^{i}} S^{i}=k^{i}$ in equilibrium. The Leviathan perceives the tax base to be inelastic. The transfer system therefore completely insulates the budget from capital mobility.
} 


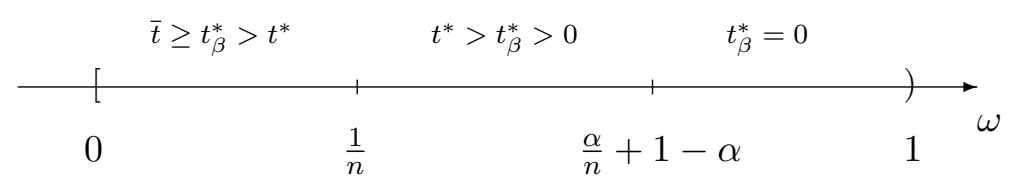

Figure 1: Illustration of Proposition 2 for $\alpha \in(0,1)$ and $n \in(1, \infty)$.

so as to completely offset the disciplining constraints imposed by fiscal competition. Supporting the cartelization hypothesis, Leviathan monopoly power is fully regained by transfers. In sum, with large open regions and pure Leviathans the equalization system sustains a tax cartel, i.e. $t_{\beta}^{*}>t^{*}$. Any unilateral downward deviation in the tax rate is punished by grant appropriation.

In a small open region fiscal equalization, however, is neutral with respect to tax policy contrasting the Brennan-Buchanan conjecture. In the absence of "political" constraints $(\omega \equiv 0)$, the Leviathan chooses $\epsilon^{i}=1$ both with and without transfers (compare Eqs. (7) and (8)). The intuition for the neutrality result is that given by Eq. (6) the collusion effect vanishes in a small open region. Since the implicit tax rate is proportional to "before-tax" marginal tax revenues, $\frac{\partial}{\partial t^{i}} t^{i} k^{i}$, the latter is set to zero in equilibrium. Taxing incentives are thus equivalent to those prevailing with $\beta^{i}(\cdot) \equiv 0$

With the weight attached to the well-being of constituents being positive (moderate Leviathan), the first-order condition becomes

$$
\epsilon^{i}=1+\frac{\alpha}{n(1-\alpha)}-\frac{\omega}{1-\alpha}, \quad \alpha \in(0,1)
$$

for an interior solution. The Leviathan's optimal tax policy is characterized in Proposition 2.

Proposition 2: (Moderate Leviathan) Let $\omega>0$ and $\alpha \in(0,1]$. With large and small open regions $(n>1)$ we have $t_{\beta}^{*} \gtreqless t^{*}$ if and only if $\omega n \lesseqgtr 1$ (with a possibly binding upper tax rate constraint, $\left.t_{\beta}^{*} \leq \bar{t}\right)$. In particular, for $\omega n \geq \alpha+n(1-\alpha)$, $t_{\beta}^{*}=0$. 
For $\omega>0$ the tax base elasticity might well drop below the value $1-\omega$ prevailing without transfers, but might also magnify possibly leading to "overtaxation" $\left(\epsilon^{i}>\right.$ $1>1-\omega)$. The ambiguity arises since extracting one unit of tax revenues from tax payers inflicts a cost of $\omega$ on the Leviathan. The cost has to be weighed against the marginal effects on $S^{i}$. With $\omega>0$, the implicit tax effect adds to the cost of taxation from the perspective of the Leviathan, while the collusion effect lowers it. ${ }^{12}$ In general, $t_{\beta}^{*}<t^{*}$ cannot be ruled out as an equilibrium outcome. In fact, provided the economy is sufficiently decentralized, $\omega n>1$, the implicit tax effect dominates the collusion effect, which disciplines the Leviathan in its attempt to extract resources. Moreover, the Leviathan's desire is completely checked by fiscal equalization $\left(t_{\beta}^{*}=0\right)$ if $\omega n>\alpha+n(1-\alpha)$. Figure 1 illustrates the tax rate differential $t^{*}-t_{\beta}^{*}$ for varying values of $\alpha, \omega$ and $n$. A higher degree of decentralization, $n$, increases the potential for transfers to lower the tax rate below $t^{*}$. Similarly, a higher equalization parameter $\alpha$ widens scope for $t_{\beta}^{*}=0$ by reducing the threshold level at which $t_{\beta}^{*}$ drops to zero. ${ }^{13}$

Proposition 2 implies:

Corollary: (Moderate Leviathan and Full Equalization) With a moderate Leviathan and full equalization, the tax rate $t_{\beta}^{*}$ is zero if the implicit tax effect dominates the collusion effect (i.e. $\omega n>1$ ). Consequently, in a small open economy $(n \rightarrow \infty)$ the Leviathan is perfectly tamed, $t^{*}>t_{\beta}^{*}=0$.

In the presence of full equalization $(\alpha=1)$, the implicit tax effect will become sufficiently pronounced so as to yield a zero tax rate if $\omega n>1$. For $n \rightarrow \infty$,

\footnotetext{
${ }^{12}$ Formally, dividing the first-order condition $\omega \frac{\partial}{\partial t^{i}} c^{i}+\frac{\partial}{\partial t^{i}} S^{i}=0$ (see Eqs. (5) and (6)) by $\left[1-\alpha\left(\frac{n-1}{n}\right)\right]$, the collusion effect and the weight attached to the costs, incurred on constituents, become more pronounced. Relative to the first-order condition without transfers, we have an additional collusion term and a magnified cost term. These countervailing effects give scope for $t_{\beta}^{*}<t^{*}$, indicating a dominating implicit tax effect.

${ }^{13} \mathrm{In}$ contrast, the threshold value at which $t_{\beta}^{*}=t^{*}$ is independent of $\alpha$ since $t^{*}$ is only influenced by $n$ and $\omega$. Besides its effect on the upper threshold value, $\alpha$ impacts the scale of the tax differential $t^{*}-t_{\beta}^{*}$ within each interval depicted in Figure 1. In particular, the magnitude of $t_{\beta}^{*}$ is positively influenced if $n \omega<1$ and negatively if $\frac{1}{n}<\omega<\frac{\alpha}{n}+1-\alpha$. This finding straightforwardly deduces from Eq. (12) in the Appendix.
} 
the aforementioned condition is unambiguously satisfied which perfectly tames the Leviathan for any slightly positive value of $\omega$. This is because the collusion effect vanishes in a small open economy; see Eq. (6). The remaining implicit tax effect induces an implicit tax rate approaching 100\%. Traded off against the cost of taxation, $\omega \frac{\partial}{\partial t^{2}} c^{i}$, it effectively eliminates incentives to divert resources. ${ }^{14}$

\section{Welfare}

Proposition 2 shows that for $\omega n>1$ equalizing-transfers yield a lower equilibrium tax rate (possibly being zero). Important for a welfare (constitutional) analysis, this leaves the question as to whether lower tax rates unambiguously benefit the taxpayer unaddressed. If the whole surplus is indeed consumed by the Leviathan, as assumed so far, and the taxpayer's interest is only decisive at the constitutional stage, the welfare implications are straightforward. Disciplining transfers tend to align Leviathan's and constituents' interests since lower tax rates allow for a higher level of private consumption. A constitutionally granted level of decentralization and equalization as reported in the Corollary induces such an alignment of interests. The welfare prescriptions will be less straightforward if one assumes that the constitution is not exclusively designed to express the taxpayers' preference as generally assumed (e.g. Brennan and Buchanan, 1980). Under the veil of ignorance each voter anticipates that with a positive probability he will be picked as a member of the "Leviathan group" at the post-constitutional level (West and Corke, 1980). Unless the probability becomes negligible, the constitutional choice will reflect the Leviathans' interest as well. In this case, the constitutionally preferred size of the public budget, subsequently denoted by $S^{*}$, will be positive. ${ }^{15}$

This raises the issue of whether constitutional provisions concerning $\alpha$ may alleviate the welfare loss or may even induce the socially preferred outcome.

\footnotetext{
${ }^{14}$ Note, following Eq. (6) the implicit tax rate $\alpha \frac{n-1}{n} \rightarrow 1$ for $\alpha=1$ and $n \rightarrow \infty$.

${ }^{15}$ Even with a negligible probability, a positive value of $S^{*}$ will be preferred at the constitutional level if a fraction of tax revenues is used to finance public goods which are valued by the taxpayer; see the extension discussed in Section 5.
} 


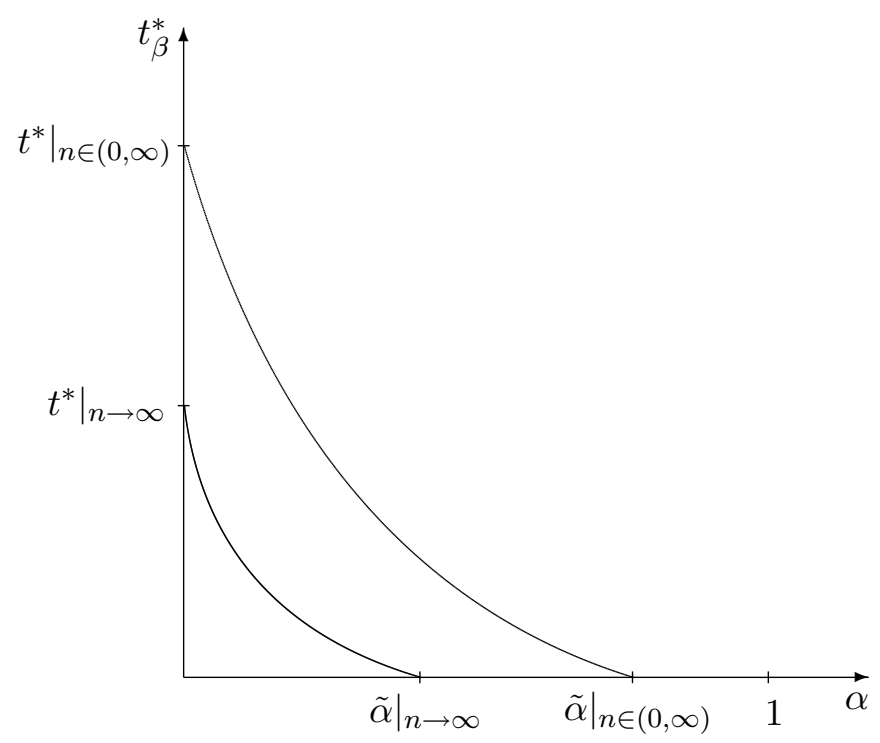

Figure 2: Equilibrium tax rate with $\omega n>1$ and $\omega \in(0,1)$.

Proposition 3: (Optimal Equalization Scheme) If the federal system is sufficiently decentralized such that $\omega n>1$, then for any value of $S^{*}$, smaller than the size of the budget in the absence of transfers, a level of equalization $\alpha^{*}$ yielding $S^{*}$ exists.

From a constitutional perspective this proposition has a straightforward implication. The preferred policy outcome can be implemented if the constitution prescribes a degree of decentralization satisfying $\omega n>1$ and a level of equalization $\alpha^{*}$. Being appropriately exposed to capital mobility and fiscal equalization, the Leviathan faces correct taxing incentives. The chosen policy outcome coincides with $S^{*}$.

One may wonder whether it isn't feasible to achieve the same outcome with tax competition in isolation. Figure 2 illustrates the tax rate as a function of $\alpha$ for regions which are large (upper curve) and small (lower curve), respectively, relative to the rest of the federation. ${ }^{16}$ Setting $\alpha=0$ yields the outcome under tax competition. Observe, even when exhausting the "gains" from decentralization by selecting

\footnotetext{
${ }^{16}$ The proof to Proposition 3 contains the derivation of the closed-form solution for the equilibrium tax rate $t_{\beta}^{*}$ depicted in Figure 2.
} 
$n \rightarrow \infty$, the equilibrium tax rate, $t^{*}$, is strictly positive. ${ }^{17}$ Introducing equalizing grants allows for magnified pressure which can even reduce the tax rate to zero (for $\alpha \in[\tilde{\alpha}, 1)) .^{18}$

\section{Extension}

So far, we have resorted to the canonical model of surplus-maximizing governments adhered to in Brennan and Buchanan (1980). Politicians extract the highest possible amount of resources from the public sector in order to finance "wasteful" consumption. Before turning to alternative objective functions, it is useful to highlight that the fundamental equation (4), which separates the incentive effects of tax revenue equalization, holds independently of the politicians' motivation. Therefore, the implicit tax effect and the collusion effect may become sufficiently strong or weak depending on the constitutionally chosen levels of $\alpha$ and $n$.

A class of Leviathan models, which has recently received attention, integrate the public finance and public choice view of government. For instance, Edwards and Keen (1996) and Sato (2003) employ a more general model of tax competition among moderate Leviathans than presented in the previous section. Edwards and Keen allow politicians to spend an endogenously determined fraction of the budget on socially-valuable public services and "waste". Besides introducing public good provision, Sato explicitly models rent-seeking as the source of political failure.

In both cases, adding equalizing-transfers, for which the implicit tax effect dominates, would increase the marginal cost of public funds. Transfers now impact welfare twofoldly. They still correct for political distortions (e.g. the reduction of "waste" in Edwards and Keen or of rent-seeking activities in Sato), but also aggravate the inefficiency in public good provision. Note, since political inefficiencies

\footnotetext{
${ }^{17}$ Letting $n \rightarrow \infty$ increases the tax base response in absolute terms but it is still finite; see Eq. (2).

${ }^{18}$ The degree of equalization at which the tax rate becomes zero reads $\tilde{\alpha}:=\frac{(1-\omega) n}{n-1} \in(0,1)$. It becomes $1-\omega$ in a small open economy; see the proof to Proposition 3.
} 
represent the price the taxpayer has to pay for partially-selfish politicians to provide public goods, it is optimal from the taxpayer's point of view to leave some rents to politicians. The second-best size of the budget, $S^{*}$, is generally strictly positive. In these hybrid models transfers continue to be desirable from a constitutional perspective if decentralization (higher $n$ ) alone is insufficient to implement the preferred policy outcome, $S^{*} \cdot{ }^{19}$ Fiscal equalization might still be an appropriate institution to limit the size of the budget.

\section{Concluding Remarks}

The paper takes the fiscal cartelization hypothesis to a formal analysis. While the Brennan-Buchanan view predicts that beneficiary tax competition will be undermined by transfers, the present analysis arrives at an ambiguous effect if transfers are set so as to equalize tax revenues. Equalizing transfers can potentially limit the expropriation of constituents adding to the protective effect of fiscal competition. The result critically depends on the size of the implicit tax effect and the collusion effect inherent in the transfer formula. Evaluating the incentive effects of the tax revenue equalization scheme implemented among German states, Baretti et al. (2002) estimate implicit tax rates ranging from 70\% to $95 \%$ (depending on state size). Lending some empirical support against the Brennan-Buchanan conjecture, these tax rates are sufficiently high to severely constrain tax policy. However, as shown in the present paper, the overall incentive effect cannot be deduced based on these findings. Complementary estimates of the collusion effect are needed to firmly assess the cartelization hypothesis - an avenue for future empirical research.

The result crucially depends on the design of the equalization formula. A different type of equalization program frequently in place is guided by the notion of a representative tax system. Entitlement payments are responsive to differences in the taxing capacity (using standardized tax rates) rather than actual per-capita

\footnotetext{
${ }^{19}$ The potential insufficiency of decentralization to appropriately tame the Leviathan might also derive from the fact that the drawing of regional boundaries is subject to so far neglected geographical or ethnical constraints. They apply less when choosing $\alpha$.
} 
tax revenues. Unlike tax-revenue equalization considered in the paper, this transfer scheme performs consistently with the notion of cartelization (see Bucovetsky and Smart, 2002 and Köthenbürger, 2002). ${ }^{20}$ A higher level of taxation depresses the tax base (taxing capacity) relative to the standard which unambiguously lures additional transfers to the tax-raising region. The improved taxing incentives at least partly undo the discipline of competitive federalism. Grossman and West (1994) find empirical evidence for the collusive character of this type of equalization scheme in Canada where it has gradually been adopted over the second half of the 20th century. Over the same time span, provincial taxing powers have partially been given up to the central government, whereas the collusion-enhancing equalization system has been used to refund centrally-collected tax revenues to provinces. Consistent with the Brennan-Buchanan conjecture, higher federal transfers as a share of provincial and local governments receipts went along with a larger share of government expenditure in the GNP at lower levels of government.

To conclude, the paper suggests that if selfish politicians and bureaucrats expand the public budget beyond its "optimal" size, equalizing transfers might serve as an effective constitutional constraint on taxing powers - a beneficial effect previously unnoticed.

\footnotetext{
${ }^{20}$ In the context of our model, the equalization formula reads

$$
\beta^{i}\left(t^{i}, \boldsymbol{t}^{-i}\right):=\alpha \bar{t}\left[\bar{k}-k^{i}\right], \quad \alpha \in[0,1],
$$

where $\bar{t}$ and $\bar{k}$ denote the representative tax rate and tax base, respectively. Taking both as parameters of the formula, a marginally higher tax rate raises transfer payments, i.e. $\frac{\partial}{\partial t^{i}} \beta^{i}(\cdot)=$ $-\alpha \bar{t} \frac{\partial}{\partial t^{i}} k^{i}>0$. Although the results in Bucovetsky and Smart (2002) and Köthenbürger (2002) are derived for benevolent governments, the effect prevails independently of the government's motivation.
} 


\section{A Appendix}

Helpful in all subsequent proofs, we first derive the first-order condition of the Leviathan's optimization problem. Following the capital market clearing condition $\sum_{j=1, j \neq i}^{n} \frac{\partial}{\partial t^{i}} k^{j}=-\frac{\partial}{\partial t^{i}} k^{i}$. Using this result and imposing symmetry Eqs. (2), (4) and (6) imply

$$
\omega \frac{\partial c^{i}}{\partial t^{i}}+\frac{\partial S^{i}}{\partial t^{i}}=\left[-\omega-(1-\alpha) \epsilon^{i}+1-\alpha \frac{n-1}{n}\right] \tilde{k} \gtreqless 0, \quad \omega \in[0,1) .
$$

\section{A.1 Proof of Proposition 1}

Assume $\omega \equiv 0$. $(i)$ Let $n \in(1, \infty)$. For $\alpha \in(0,1)$ there is always a non-zero tax rate satisfying Eq. (11) as an equality. Rewriting the first-order condition, the interior solution follows from $\epsilon^{i}=1+\frac{\alpha}{n(1-\alpha)}$. Comparing with Eq. (7) reveals $t^{*}<t_{\beta}^{*}$. To cover for the possibility of $t^{i} \leq \bar{t}$ being binding, we have $t^{*}<t_{\beta}^{*} \leq \bar{t}$. For $\alpha=1$, the term in Eq. (11) becomes strictly positive. Thus, $t_{\beta}^{*}=\bar{t}$.

(ii) If $n \rightarrow \infty$, Eq. (11) reads $-(1-\alpha)\left(\epsilon^{i}-1\right)$. An interior solution exists for $\alpha \in(0,1)$ which coincides with the solution to Eq. (7). Thus, $t^{*}=t_{\beta}^{*}$. In the case of full equalization, $\alpha=1$, the optimal tax rate is undetermined. In fact, any value of $t^{i} \in[0, \bar{t}]$ can be sustained as an equilibrium tax rate. To resolve the indeterminacy, we adopt the tie-breaking rule $t^{*}=t_{\beta}^{*}$ if $\alpha=1$.

\section{A.2 Proof of Proposition 2}

Assume $\omega>0$. Let $n>1$. Given by the non-negativity constraint on $t^{i}$ Eq. (11) cannot hold as an equality if $\omega n \geq \alpha+n(1-\alpha)$. In this case Eq. (11) becomes unambiguously negative yielding $t_{\beta}^{*}=0$. Conversely, if $\omega n<\alpha+n(1-\alpha)$, existence of a non-zero tax rate satisfying Eq. (11) as an equality is guaranteed.

If $\alpha \in(0,1)$ the corresponding first-order condition reads $\epsilon^{i}=1+\frac{\alpha}{n(1-\alpha)}-\frac{\omega}{1-\alpha}$. Comparing with Eq. (7) and rearranging gives $\omega \lesseqgtr \frac{1}{n} \Leftrightarrow t_{\beta}^{*} \gtreqless t^{*}$. A possibly binding upper constraint $t^{i} \leq \bar{t}$ is reflected by $t_{\beta}^{*} \leq \bar{t}$. 
For $\alpha=1$ we get

$$
t_{\beta}^{*}=\left\{\begin{array}{rlrl}
\bar{t} & & < \\
t^{*} & \text { if } & \omega & =\frac{1}{n}, \\
0 & & & >
\end{array}\right.
$$

which follows from inserting $\alpha=1$ in Eq. (11). Note, for $\omega=\frac{1}{n}$ the optimal tax rate is undetermined. In this case we adopt the tie-breaking rule $t^{*}=t_{\beta}^{*}$. Thus, $t_{\beta}^{*} \gtreqless t^{*} \Leftrightarrow \omega \lesseqgtr \frac{1}{n}$. Finally, note that $\omega n \geq \alpha+n(1-\alpha)$ implies $\omega>\frac{1}{n}$ for $n>1$. Combining all results proves Proposition 2.

\section{A.3 Proof of Proposition 3}

Given by Proposition 2 Eq. (11) is satisfied as an equality if $\omega n<\alpha+n(1-\alpha)$. Thus, the non-negativity constraint on $t^{i}$ becomes binding for $\alpha>\tilde{\alpha}$ where $\tilde{\alpha}:=\frac{(1-\omega) n}{n-1}$. Using the definition of $\epsilon^{i}$ (Eq. (7)) the interior solution can be computed as

$$
t_{\beta}^{*}=-\frac{n}{n-1} f^{\prime \prime}(\tilde{k})\left[1+\frac{\alpha}{n(1-\alpha)}-\frac{\omega}{1-\alpha}\right] .
$$

Following Proposition $2 t^{*}>t_{\beta}^{*}$ if $\omega n>1$. Under this condition the tax rate exhibits two important properties. Firstly, observe that the equilibrium tax rate is continuous and strictly decreasing in $\alpha \in(0, \tilde{\alpha})$ and equal to zero for $\alpha \in[\tilde{\alpha}, 1)$, where $\tilde{\alpha} \in(0,1)$ since $\omega \in(0,1)$. Secondly, $t_{\beta}^{*} \rightarrow t^{*}$ if $\alpha \rightarrow 0$. Thus, if $t^{*} \tilde{k}>S^{*}$, the intermediate value theorem guarantees an equalization parameter $\alpha^{*} \in(0, \tilde{\alpha})$ for a positive value of $S^{*}$ such that $t_{\beta}^{*} \tilde{k}=S^{*}$. If $S^{*}=0$, any equalization parameter $\alpha^{*} \in[\tilde{\alpha}, 1)$ implements the preferred allocation which completes the proof. 


\section{References}

[1] Baretti, C., B. Huber, and K. Lichtblau (2002). A Tax on Tax Revenues - The Incentive Effects of Equalizing Transfer: Evidence From Germany: International Tax and Public Finance 9: 631-649.

[2] Boadway, R. and F.R. Flatters (1982). Efficiency and Equalization Payments in a Federal System of Government - A Synthesis and Extension of Recent Results. Canadian Journal of Economics 15: 613 - 633.

[3] Brennan, G. and J. Buchanan (1977). Towards a Tax Constitution for Leviathan. Journal of Public Economics 8: 255 - 273.

[4] Brennan, G. and J. Buchanan (1980). The Power To Tax: Analytical Foundations of a Fiscal Constitution. Cambridge University Press, Cambridge.

[5] Buchanan, J. (1952). Federal Grants and Resource Allocation. Journal of Political Economy 60: 208 - 217.

[6] Bucovetsky, S. and M. Smart (2002). The Efficiency Consequences of Local Revenue Equalization: Tax Competition and Tax Distortions. CESifo Working Paper No. 767, Munich.

[7] Edwards, J. and M. Keen (1996). Tax Competition and Leviathan. European Economic Review 40: 113 - 134.

[8] Flowers, M.R. (1988). Shared Tax Sources in a Leviathan Model of Federalism. Public Finance Quarterly 16: 67 - 77.

[9] Grossman, P.J. and E.G. West (1994). Federalism and the Growth of Government Revisited. Public Choice 79: 19-32.

[10] Gordon, R. and J.D. Wilson (2003). Expenditure Competition. Journal of Public Economic Theory 5: 399 - 417. 
[11] Epple, D. and A. Zelenitz (1981). The Implications of Competition Among Jurisdictions: Does Tiebout Need Politics?. Journal of Political Economy 89: $1197-1217$.

[12] Hange, U. and D. Wellisch (1998). The Benefit of Fiscal Decentralization. Finanzarchiv 55: 315-327.

[13] Keen, M. (1998). Vertical Tax Externalities in the Theory of Fiscal Federalism. IMF Staff Papers 45: 454 - 485.

[14] Köthenbürger, M. (2002). Tax Competition and Fiscal Equalization. International Tax and Public Finance 9: 391 - 408.

[15] Sato, M. (2003). Tax Competition, Rent-Seeking and Fiscal Decentralization. European Economic Review 47: 19 - 40.

[16] West, E.G. and G. Corke (1980). Tax Constraints on Leviathan. Journal of Public Economics 13: 395 - 401.

[17] Wrede, M. (2000). Shared Tax Sources and Public Expenditures. International Tax and Public Finance 2: 163 - 175.

[18] Wrede, M. (1996). Vertical and Horizontal Tax Competition: Will Uncoordinated Leviathans End Up on the Wrong Side of the Laffer Curve?. Finanzarchiv 53: $461-479$. 


\section{CESifo Working Paper Series}

(for full list see www.cesifo.de)

1117 Gianmarco I.P. Ottaviano and Giovanni Peri, The Economic Value of Cultural Diversity: Evidence from US Cities, January 2004

1118 Thorvaldur Gylfason, Monetary and Fiscal Management, Finance, and Growth, January 2004

1119 Hans Degryse and Steven Ongena, The Impact of Competition on Bank Orientation and Specialization, January 2004

1120 Piotr Wdowinski, Determinants of Country Beta Risk in Poland, January 2004

1121 Margarita Katsimi and Thomas Moutos, Inequality and Redistribution via the Public Provision of Private Goods, January 2004

1122 Martin Peitz and Patrick Waelbroeck, The Effect of Internet Piracy on CD Sales: CrossSection Evidence, January 2004

1123 Ansgar Belke and Friedrich Schneider, Privatization in Austria: Some Theoretical Reasons and First Results About the Privatization Proceeds, January 2004

1124 Chang Woon Nam and Doina Maria Radulescu, Does Debt Maturity Matter for Investment Decisions?, February 2004

1125 Tomer Blumkin and Efraim Sadka, Minimum Wage with Optimal Income Taxation, February 2004

1126 David Parker, The UK's Privatisation Experiment: The Passage of Time Permits a Sober Assessment, February 2004

1127 Henrik Christoffersen and Martin Paldam, Privatization in Denmark, 1980-2002, February 2004

1128 Gregory S. Amacher, Erkki Koskela and Markku Ollikainen, Deforestation, Production Intensity and Land Use under Insecure Property Rights, February 2004

1129 Yin-Wong Cheung, Javier Gardeazabal, and Jesús Vázquez, Exchange Rate Dynamics: Where is the Saddle Path?, February 2004

1130 Alberto Alesina and Guido Tabellini, Bureaucrats or Politicians?, February 2004

1131 Gregory S. Amacher, Erkki Koskela, and Markku Ollikainen, Socially Optimal Royalty Design and Illegal Logging under Alternative Penalty Schemes, February 2004

1132 David M. Newbery, Privatising Network Industries, February 2004 
1133 Charles Yuji Horioka, The Stagnation of Household Consumption in Japan, February 2004

1134 Eiji Fujii, Exchange Rate Pass-Through in the Deflationary Japan: How Effective is the Yen's Depreciation for Fighting Deflation?, February 2004

1135 Mark M. Spiegel and Nobuyoshi Yamori, Determinants of Voluntary Bank Disclosure: Evidence from Japanese Shinkin Banks, Febrary 2004

1136 Robert Dekle and Kenneth Kletzer, Deposit Insurance, Regulatory Forbearance and Economic Growth: Implications for the Japanese Banking Crisis, February 2004

1137 Takatoshi Ito and Kimie Harada, Bank Fragility in Japan, 1995-2003, February 2004

1138 Kunio Okina and Shigenori Shiratsuka, Policy Duration Effect under Zero Interest Rates: An Application of Wavelet Analysis, February 2004

1139 Francine D. Blau and Lawrence M. Kahn, Do Cognitive Test Scores Explain Higher U.S. Wage Inequality?, February 2004

1140 Michael Rauscher, Economic Growth and Tax-Competing Leviathans, February 2004

1141 Ernst Fehr and Jean-Robert Tyran, Money Illusion and Coordination Failure, February 2004

1142 Ingo Vogelsang, Network Utilities in the U.S. - Sector Reforms without Privatization, March 2004

1143 Marc-Andreas Muendler, Estimating Production Functions When Productivity Change is Endogenous, March 2004

1144 Sascha O. Becker, Samuel Bentolila, Ana Fernandes, and Andrea Ichino, Job Insecurity and Children's Emancipation, March 2004

1145 Pascalis Raimondos-Møller and Alan D. Woodland, Non-Preferential Trading Clubs, March 2004

1146 Robert Fenge and Matthias Wrede, EU Regional Policy: Vertical Fiscal Externalities and Matching Grants, March 2004

1147 Chi-Yung Ng and John Whalley, Geographical Extension of Free Trade Zones as Trade Liberalization: A Numerical Simulation Approach, March 2004

1148 Marc-Andreas Muendler, Trade, Technology, and Productivity: A Study of Brazilian Manufacturers, 1986-1998, March 2004

1149 Eugene Beaulieu, Vivek H. Dehejia, and Hazrat-Omar Zakhilwal, International Trade, Labour Turnover, and the Wage Premium: Testing the Bhagwati-Dehejia Hypothesis for Canada, March 2004 
1150 Giorgio Brunello and Francesca Gambarotto, Agglomeration Effects on EmployerProvided Training: Evidence from the UK, March 2004

1151 S. Brock Blomberg, Gregory D. Hess, and Athanasios Orphanides, The Macroeconomic Consequences of Terrorism, March 2004

1152 Bodo Sturm and Joachim Weimann, Unilateral Emissions Abatement: An Experiment, March 2004

1153 Wolfgang Ochel, Welfare-to-Work Experiences with Specific Work-First Programmes in Selected Countries, March 2004

1154 Jan K. Brueckner and Eric Pels, European Airline Mergers, Alliance Consolidation, and Consumer Welfare, March 2004

1155 Aaron Tornell, Frank Westermann, and Lorenza Martínez, NAFTA and Mexico's Economic Performance, March 2004

1156 George Economides, Sarantis Kalyvitis, and Apostolis Philippopoulos, Do Foreign Aid Transfers Distort Incentives and Hurt Growth? Theory and Evidence from 75 Aidrecipient Countries, March 2004

1157 Robert Fenge and Volker Meier, Are Family Allowances and Fertility-related pensions Siamese Twins?, March 2004

1158 Bruno S. Frey, Simon Luechinger, and Alois Stutzer, Valuing Public Goods: The Life Satisfation Approach, March 2004

1159 Jerome L. Stein and Guay C. Lim, Asian Crises: Theory, Evidence, Warning-Signals, March 2004

1160 Romain Ranciere, Aaron Tornell, and Frank Westermann, Crises and Growth: A ReEvaluation, March 2004

1161 Assaf Razin and Efraim Sadka, Transparency, Specialization and FDI, March 2004

1162 Ludger Woessmann, How Equal Are Educational Opportunities? Family Background and Student Achievement in Europe and the United States, March 2004

1163 B.M.S. van Praag and Barbara E. Baarsma, Using Happiness Surveys to Value Intangibles: The Case of Airport Noise, March 2004

1164 Aaron Tornell, Frank Westermann, and Lorenza Martínez, The Positive Link Between Financial Liberalization, Growth, and Crises, March 2004

1165 Helge Berger and Carsten Hefeker, One Country, One Vote? Labor Market Structure and Voting Rights in the ECB, March 2004

1166 Clemens Fuest and Martin Kolmar, A Theory of User-Fee Competition, March 2004 
1167 Friedrich Schneider and Robert Klinglmair, Shadow Economies around the World: What Do We Know?, April 2004

1168 Horst Raff and Nicolas Schmitt, Exclusive Dealing and Common Agency in International Markets, April 2004

1169 M. Hashem Pesaran and Allan Timmermann, Real Time Econometrics, April 2004

1170 Sean D. Barrett, Privatisation in Ireland, April 2004

1171 V. Anton Muscatelli, Patrizio Tirelli and Carmine Trecroci, Can Fiscal Policy Help Macroeconomic Stabilisation? Evidence from a New Keynesian Model with Liquidity Constraints, April 2004

1172 Bernd Huber and Marco Runkel, Tax Competition, Excludable Public Goods and User Charges, April 2004

1173 John McMillan and Pablo Zoido, How to Subvert Democracy: Montesinos in Peru, April 2004

1174 Theo Eicher and Jong Woo Kang, Trade, Foreign Direct Investment or Acquisition: Optimal Entry Modes for Multinationals, April 2004

1175 Chang Woon Nam and Doina Maria Radulescu, Types of Tax Concessions for Attracting Foreign Direct Investment in Free Economic Zones, April 2004

1176 M. Hashem Pesaran and Andreas Pick, Econometric Issues in the Analysis of Contagion, April 2004

1177 Steinar Holden and Fredrik Wulfsberg, Downward Nominal Wage Rigidity in Europe, April 2004

1178 Stefan Lachenmaier and Ludger Woessmann, Does Innovation Cause Exports? Evidence from Exogenous Innovation Impulses and Obstacles, April 2004

1179 Thiess Buettner and Johannes Rincke, Labor Market Effects of Economic Integration The Impact of Re-Unification in German Border Regions, April 2004

1180 Marko Koethenbuerger, Leviathans, Federal Transfers, and the Cartelization Hypothesis, April 2004 